\title{
HUBUNGAN ANTARA KONDISI KESEHATAN IBU, PELAKSANAAN IMD, DAN IKLAN SUSU FORMULA DENGAN PEMBERIAN ASI EKSKLUSIF
}

\author{
Relationship Between Maternal Health Conditions, Imd Implementation, \\ and Milk Formula Ads With Exclusive Assembling
}

\author{
Dedi Alamsyah', Marlenywati², Hasti Ruthayana ${ }^{2}$ \\ ${ }^{1}$ Dosen Peminatan Epidemiologi Kesehatan Masyarakat \\ 2Dosen Peminatan Gizi Kesehatan Masyarakat \\ 2Mahasiswa Peminatan Gizi Kesehatan Masyarakat \\ Fakultas Ilmu Kesehatan Universitas Muhammadiyah Pontianak \\ Email: alamsyahdedi89@yahoo.co.id
}

\begin{abstract}
Exclusive breastfeeding means that the infant receives only breast milk. No other liquids or solids are given. Breastfeeding is influenced by a number of factors, such maternal health condition, early initiation of breastfeeding, and infant formula advertising. Data from Health Department of Kabupaten Sambas indicated that that the coverage of breastfeeding in Kecamatan Tangaran, in 2014, was 27,1\% and it ranked the first of 19 districts with low coverage of breastfeeding. This study aimed at analyzing the correlation of maternal health condition, early initiation of breastfeeding, infant formula advertising, and exclusive breastfeeding in Kecamatan Tangaran Kabupaten Sambas.Using observational analytic design and cross sectional approach, this study employed 110 samples. Each variable was tested using chi square test.The results indicated that early initiation of breastfeeding ( $p$ value $=0,047$ ) has significant correlation with exclusive breastfeeding ( $p$ value=0,05). Meanwhile, maternal health condition ( $p$ value $=0,071$ ) doesn't significantly correlate with infant formula advertising ( $p$ value $=0,606$ ). From the findings, the health personnel are encouraged to inform the young mothers about exclusive breastfeeding, provide lactation clinic, and impose sanctions for birth attendants who do not perform early initiation of breastfeeding birth. Also pregnant women are encouraged to choose early initiation of breastfeeding birth. At last, further researcher need to have further discussion about the factors of exclusive breastfeeding.
\end{abstract}

Keyword keys :Early Initiation of Breastfeeding, Exclusive Breastfeeding.

\begin{abstract}
Abstrak
ASI eksklusif adalah pemberian ASI saja pada bayi sampai usia 6 bulan tanpa tambahan cairan ataupun makanan lain. Pemberian ASI secara eksklusif dipengaruhi oleh beberapa faktor seperti kondisi kesehatan ibu, pelaksanaan inisiasi menyusu dini (IMD), dan iklan susu formula. Data yang diperoleh dari laporan petugas gizi berkaitan cakupan ASI eksklusif di Kecamatan Tangaran pada tahun 2014 hanya 27,1\% dan merupakan urutan

${ }^{1}$ Dedi Alamsyahadalah Dosen Peminatan Epidemiologi Fakultas Ilmu Kesehatan Universitas Muhammadiyah Pontianak

2 Marlenywati dan Hasti Ruthayanaadalah Dosen Peminatan GiziFakultas Ilmu Kesehatan Universitas Muhammadiyah Pontianak
\end{abstract}


pertama yang memiliki cakupan ASI eksklusif terendah dari 19 Kecamatan.Kondisi kesehatan ibu, pelaksanaan IMD, dan iklan susu formula mempengaruhipemberian ASI eksklusif di Kecamatan Tangaran Kabupaten Sambas. Penelitian ini menggunakan desain cross sectional.Besar sampel dalam penelitian ini adalah 110 sampel. Adapun cara pengambilan sampel menggunakan simple random samplingdi Kecamatan Tangaran.Masing-masing variabel yang diteliti diuji dengan menggunakan uji Chisquare.Hasil penelitian ini menunjukkan bahwa pelaksanaan IMD ( $p$ value $=0,047)$ memiliki hubungan yang signifikan dengan pemberian ASI ekskluif dengan nilai $p$ value < 0,05 , sedangkan kondisi kesehatan ibu $(p$ value $=0,071)$ dan iklan susu formula ( $p$ value $=$ 0,606 ) tidak terdapat hubungan yang signifikan.Saran bagi tenaga kesehatan dan dinas kesehatan untuk memberikan penjelasan mengenai pemberian ASI eksklusif, menyediakan klinik laktasi, persalinanditolong oleh bidan (tenaga kesehatan).

Kata Kunci :Faktor IMD,ASI Eksklusi.

\section{PENDAHULUAN}

Menyusui sejak dini mempunyai dampak yang positif baik bagi ibu maupun bayinya. Bagi bayi, menyusui mempunyai peran penting untuk menunjang pertumbuhan, kesehatan, dan kelangsungan hidup bayi karena ASI kaya dengan zat gizi dan antibody, Sedangkan bagi ibu, menyusui dapat mengurangi morbiditas dan mortalitas karena proses menyusui akan merangsang kontraksi uterus sehingga mengurangi perdarahan pasca melahirkan (postpartum). Menyusui dalam jangka panjang dapat memperpanjang jarak kelahiran.[1] Kekurangan menyusui pada bayi mengakibatkan Kekurangan zat gizi pada makanan bayi dapat mengganggu pertumbuhan dan Perkembangan bayi. Selain itu, bayi menjadi lebih rentan terhadap penyakit-penyakit infeksi yang berdampak terhadap menurunnya derajat kesehatan. Gizi untuk bayi yang paling sempurna dan paling murah bagi bayi adalah air susu ibu (ASI).[2]

Air Susu Ibu (ASI) adalah makanan terbaik bagi bayi karena dapat memberikan dampak-dampak yang positif bagi perkembangan anak fisik, kognitif, dan emosional.ASI dapat mencegah malnutrisi karena ASI mengandung zat-zat gizi yang dibutuhkan oleh tubuh bayi dan melindungi bayi terhadap infeksi. Selain itu, banyak bukti ilmiah yang menunjukan bayi yang mendapatkan ASI terhindar dari obesitas.[3]

Menurut Depkes (2008) ASI ekslusif adalah pemberian ASI saja pada bayi sejak lahir sampai berusia 6 bulan tanpa tambahan cairan lain, seperti susu formula, jeruk, madu, air teh, air putih, dan makanan padat seperti pisang, pepaya, bubur susu, biskuit, bubur nasi, tim serta obat-obatan dan vitamin. ASI yang diberikan kepada bayi secara eksklusif banyak memiliki manfaat dan kelebihan yaitu dapat menurunkan risiko penyakit infeksi misalnya : diare, infeksi saluran nafas, dan infeksi telinga.[4]0leh karena itu, United Nations International Children's Emergency Fund (UNICEF) dan World Health Organization (WHO) membuat rekomendasi pada ibu untuk menyusui eksklusif selama 6 bulan kepada bayinya. Sesudah umur 6 bulan, bayi baru dapat diberikan makanan pendamping ASI (MP-ASI) dan ibu tetap memberikan ASI sampai anak berumur minimal 2 tahun. Pemerintah Indonesia 
melalui Kementerian Kesehatan juga merekomendasikan para ibu untuk menyusui eksklusif selama 6 bulan kepada bayinya.[1]

Menurut WHO dan UNICEF di Negara industri, bayi yang tidak diberi ASI eksklusif lebih besar memiliki risiko meninggal dari pada bayi yang diberi ASI eksklusif. Pemberian ASI eksklusif selama 6 bulan dihubungkan dengan penurunan kasus diare $(53,0 \%)$ dan ISPA $(27,0 \%)$, sedangkan di Negara berkembang hanya 39\% ibu-ibu yang memberikan ASI eksklusif.[5]Pemberian ASI eksklusif di Indonesia masih jauh dari harapan. Berdasarkan hasil Survei Sosial Ekonomi Nasional (Susenas) Tahun 2010, cakupan pemberian ASI eksklusif pada bayi usia 0-6 bulan di Indonesia 61,5\% dan di Kalbar 50,9\%.[6]

Menurut data Riskesdastahun 2013 Persentase pemberian ASI eksklusif di Indonesia dalam 24 jam terakhir tanpa riwayat diberikan makanan dan minuman selain ASI pada umur 6 bulan sebesar 30,2\%, dan Inisiasi menyusu dini kurang dari satu jam setelah bayi lahir adalah 31,3\%. Riskesdas tahun 2010 persentase menyusui eksklusif semakin menurun dengan meningkatnya kelompok umur bayi. Pada bayi yang berumur 5 bulan menyusui eksklusif hanya $15,3 \%$, dan persentase proses mulai menyusui kurang dari satu jam (< 1 jam) setelah bayi lahir adalah hanya 29,3\%.[1]

Berdasarkan profil kesehatan

Provinsi Kalbar cakupan ASI eksklusif sebesar 49,5\%. Dari Profil kesehatan Provinsi Kalimantan Barat, Kabupaten Sambas merupakan salah satu yang memiliki cakupan ASI eksklusif terendah dari 14 Kabupaten. Cakupan pemberian ASI eksklusif di Kabupaten Sambas mengalami peningkatan setiap tahunnya dari tahun 2012-2014, pada tahun 2012 cakupan pemberian ASI eksklusif sebanyak 13,1\%, pada tahun 2013 sebanyak 51,89\%, dan tahun 2014 sebanyak 69,2\%7. Walaupun cakupan ASI ekskusif tersebut terus mengalami peningkatan tetapi masih dibawah SPM (Standar Pelayanan Minimal) yaitu 80\%. Dari data dinas kesehatan Kabupaten Sambas tahun 2014, Kecamatan Tangaran merupakan urutan pertama yang memiliki cakupan ASI eksklusif terendah yaitu sebesar 27,1\% dari 19 Kecamatan yang terdapat di kabupaten Sambas.[8]

Hasil survey pendahuluan yang dilakukan kepada 10 ibu yang memiliki bayi berumur 0-6 bulan di Kecamatan Tangaran Kabupaten Sambas tahun 2015 dengan menggunakan teknik wawancara menggunakan kuesioner, diketahui bayi yang tidak mendapatkan ASI eksklusif sebanyak 6 bayi (60\%), ibu dalam keadaan sakit saat menyusui (pembengkakan payudara, puting susu lecet (luka), melahirkan dengan operasi Caesar) sebanyak 4 ibu (40), ibu yang melakukan IMD sebanyak 4 ibu (40\%). dan ibu yang terpapar iklan susu formula dari TV atau poster-poster sebanyak 8 ibu $(80 \%)$.

\section{METODE PENELITIAN}

Penelitian

ini mengguanakanrancangan penelitian Cross Sectional.Penelitian dilakukan di Kecamatan Tangaran Kabupaten Sambas dan dilaksanakan pada bulan Maret-April 2016.Teknik pengambilan sampel

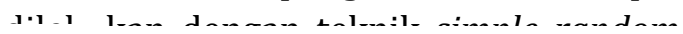

71 Jurnal IKESMA Volume 13 Nomor 1 Maret 2017 yang diperoleh sebanyak 110 orang.

Analisa yang digunakan adalah analisis univariat dan bivariat. Analisis univariat dilakukan untuk menggambarkan kesponden dan menggambarkan setiap variabel, 
sedangkan analisis bivariat dilakukan untuk mengetahui hubungan variabel independen dan variabel dependen. Penelitian ini menggunakan uji chisquare.

\section{HASIL DAN PEMBAHASAN}

\section{Karakteristik Responden}

Tabel 1. Karakteristik RespondenDistribusi Frekuensi Berdasarkan Umur, Pekerjaan, Pendidikan, Jenis Kelamin Bayi, Parita, Tempat Persalinan, Dan Penolong Persalinan

\begin{tabular}{|c|c|c|}
\hline \multirow[t]{2}{*}{ Karakteristik } & \multicolumn{2}{|c|}{ Responden } \\
\hline & $\mathbf{n}$ & $\%$ \\
\hline \multicolumn{3}{|l|}{ Umur } \\
\hline$<20$ tahun & 2 & 1,8 \\
\hline 20-35 tahun & 91 & 82,7 \\
\hline$>35$ tahun & 17 & 15,5 \\
\hline \multicolumn{3}{|l|}{ Jenis Pekerjaan } \\
\hline Petani & 52 & 47,3 \\
\hline Swasta & 5 & 4,5 \\
\hline Pegawai honor & 4 & 3,6 \\
\hline PNS & 1 & 0,9 \\
\hline Tidak bekerja/ IRT & 48 & 43,6 \\
\hline \multicolumn{3}{|l|}{ Pendidikan } \\
\hline Tidak tamat SD & 4 & 3,6 \\
\hline SD & 44 & 40 \\
\hline SMP/MTS & 38 & 34,5 \\
\hline SMA/MA/SMK & 17 & 15,5 \\
\hline Perguruan tinggi (D2,D3,S1 & 7 & 6,4 \\
\hline \multicolumn{3}{|l|}{ Jenis Kelamin Bayi } \\
\hline Laki-laki & 61 & 55,5 \\
\hline Perempuan & 49 & 44,5 \\
\hline \multicolumn{3}{|l|}{ Paritas } \\
\hline 1 & 19 & 17,3 \\
\hline 2 & 55 & 50 \\
\hline 3 & 27 & 24,5 \\
\hline 4 & 3 & 2,7 \\
\hline 5 & 5 & 4,5 \\
\hline 7 & \multirow{2}{*}{\multicolumn{2}{|c|}{ Dedi Alamsyah :Hubungan Antara KondisiKesehatan }} \\
\hline Tempat Persalinan Dedi & & \\
\hline Praktik Bidan & 28 & 25,5 \\
\hline Rumah Sakit & 16 & 14,5 \\
\hline Puskesmas & 43 & 39,1 \\
\hline Rumah & 23 & 20,9 \\
\hline
\end{tabular}




\begin{tabular}{lcc}
\hline Karakteristik & \multicolumn{2}{c}{ Responden } \\
\cline { 2 - 3 } & n & $\mathbf{\%}$ \\
\hline Penolong Persalinan & & \\
\hline Bidan & 89 & 80,9 \\
\hline Dokter & 10 & 9,1 \\
\hline Dukun & 11 & 10 \\
\hline
\end{tabular}

Dari tabel diatas dapat diketahui karakteristik responden berdasarkan umur menunjukkan bahwa responden terbanyak adalah berumur 20-35 tahun yaitu 91 responden $(82,7 \%)$.Responden berdasarkan jenis pekerjaanmenunjukkan bahwa responden terbanyak adalah sebagai petani yaitu 52 responden $(47,3)$. Responden berdasarkan pendidikan ibu menunjukkan bahwa responden terbanyak adalah tamat SD yaitu 44 responden (40\%). Karekteristik respondenberdasarkan jenis kelamin bayi yang dimiliki ibu menunjukkan bahwa responden terbanyak berjenis kelamin laki-laki yaitu 61Reponden (55,5\%). Responden berdasarkan paritas menunjukan bahwa responden terbanyak adalah memiki 2 anak yaitu 55 responden (50\%). Respondenberdasarkan tempat persalinan menunjukkan bahwaresponden terbanyak melakukan persalinan di puskesmas yaitu 43 responden

$(39,1 \%)$.Respondenberdasarkan penolong persalinan menunjukkan bahwaresponden terbanyak adalah ditolong oleh bidan yaitu 89 responden $(80,9 \%)$.

\section{Univariat}

Tabel 2. Distribusi Frekuensi Berdasarkan Variabel PenelitianKondisi Kesehatan Ibu, Pelaksanaan Inisiasi Menyusu Dini, Iklan Susu Formula, Dan Pemberian ASI Eksklusif

\begin{tabular}{|c|c|c|}
\hline \multirow[t]{2}{*}{ Variabel Penelitian } & \multicolumn{2}{|c|}{ Responden } \\
\hline & $\mathbf{n}$ & $\%$ \\
\hline \multicolumn{3}{|c|}{ Kondisi Kesehatan Ibu } \\
\hline Sakit & 67 & 60,9 \\
\hline Tidak sakit & 43 & 39,1 \\
\hline \multicolumn{3}{|l|}{ Pelaksanaan IMD } \\
\hline Tidak IMD & 78 & 70,9 \\
\hline IMD & 32 & 29,1 \\
\hline \multicolumn{3}{|c|}{ Paparan Iklan Susu Formula } \\
\hline Terpapar & 77 & 70 \\
\hline Tidak terpapar & 33 & 30 \\
\hline \multicolumn{3}{|c|}{ Pemberian ASI Eksklusif } \\
\hline Tidak ASI eksklusif & 69 & 62,7 \\
\hline ASI eksklusif & 41 & 37,3 \\
\hline
\end{tabular}


dialami yaitu puting lecet $30 \%$, payudara bengkak $44,5 \%$, mastitis $10 \%$, bedah sesar 9,1\%, diabetes $6,4 \%$ dan penyakit lain sebesar 4,5\%. Variabel pelaksanaan IMD menunjukkan bahwa responden dengan presentase terbanyak adalah responden yang tidak melaksanakan IMD yaitu 70,9\%. Kegagalan dalam penelitian ini dikarenakan ketidaksabaran ibu dalam memberi ASI kepada bayinya setelah lahir dan ibu merasa bosan jika bayi diletakan diatas dadanya terlalu lama $(<$ dari 1 jam).Variabel paparan iklan susu formula berdasarkan hasil penelitian, bahwaresponden dengan presentase terbanyak adalah responden yang terpapar iklan susu formula yaitu $70 \%$.

\section{Bivariat}

Tabel 3. Total Hubungan Antara Kondisi Kesehatan Ibu, Pelaksanaan IMD, Dan Iklan Susu Formula Dengan Pemberian ASI Eksklusif Di Kecamatan Tangaran Kabupaten Sambas

\begin{tabular}{|c|c|c|c|c|c|c|}
\hline \multirow{3}{*}{ Variabel } & \multicolumn{4}{|c|}{ Pemberian ASI Eksklusif } & \multirow{3}{*}{$\begin{array}{c}\text { Signif } \\
\text { ikan }\end{array}$} & \multirow{3}{*}{ PR 95\% CI } \\
\hline & \multicolumn{2}{|c|}{$\begin{array}{l}\text { Tidak ASI } \\
\text { Eksklusif }\end{array}$} & \multicolumn{2}{|c|}{$\begin{array}{c}\text { ASI } \\
\text { Eksklusif }\end{array}$} & & \\
\hline & $\mathbf{n}$ & $\%$ & $\mathbf{n}$ & $\%$ & & \\
\hline \multicolumn{7}{|c|}{ Kondisi Kesehatan Ibu } \\
\hline Sakit & 47 & 70,1 & 20 & 29,9 & 0,071 & 1,371 \\
\hline Tidak sakit & 22 & 51,2 & 21 & 48,8 & & $\begin{array}{c}(0,985- \\
1,909)\end{array}$ \\
\hline \multicolumn{7}{|l|}{ Pelaksanaan IMD } \\
\hline Tidak IMD & 54 & 69,2 & 24 & 30,8 & 0,47 & 1,477 \\
\hline IMD & 15 & 46,9 & 17 & 53,1 & & $\begin{array}{l}(0,993- \\
2,198)\end{array}$ \\
\hline \multicolumn{7}{|c|}{ Paparan Iklan Susu Formula } \\
\hline Terpapar & 50 & 64,9 & 27 & 35,1 & 0,606 & 1,128 \\
\hline Tidak terpapar & 19 & 57,6 & 14 & 42,4 & & $\begin{array}{c}(0,806- \\
1,578)\end{array}$ \\
\hline
\end{tabular}




\section{1) Hubungan Antara Kondisi KesehatanDengan Pemberian ASI Eksklusif}

Berdasarkan hasil penelitian yang dilakukan, jumlah responden yang tidak memberikan ASI eksklusif dalam keadaan sakit $(70,1 \%)$ lebih besar dibandingkan dengan jumlah responden yang memberikan ASI secara eksklusif dalam keadaan sehat (tidak sakit) yaitu 48,8\%. Dari hasil analisis statistik yang dilakukan diperoleh nilai $p$ value $=0,071$ lebih besar dari $\alpha=0,05$, jadi dapat disimpulkan bahwa tidak ada hubungan yang signifikan antara kondisi kesehatanibu dengan pemberian ASI eksklusif pada ibu yang memiliki bayi usia 0-6 bulan di Kecamatan Tangaran Kabupaten Sambas. Meskipin kondisi kesehatan ibu tidak meiliki hubungan yang signifikan dengan pemberian ASI eksklusif, tetapi variabel ini ada risiko untuk tidak memberiankan ASI ekslusif karena nilai $P R=1,371$.

Masalah-masalah kesehatan yang muncul pada ibu yang menyusui menyebabkan muncul keraguan dalam diri ibu, apakah ia mampu atau tidak untuk memberikan ASI kepada bayinya, kondisi tersebut pada akhirnya akan berujung kepada proses kegagalan pemberian ASI eksklusif ${ }^{9}$. Masalah kesehatan yang sering dirasakan ibu pada saat menyusui adalah pembengkakan pada payudaranya. Pembengkakan payudara terjadi karena edema ringan oleh hambatan vena atau saluran limfe akibat ASI yang menumpuk di dalam payudara. Penumpukan ASI di dalam payudara disebabkan karena bayi tidak menyusu dengan kuat, posisi pada payudara salah sehingga proses menyusu tidak benar, dan terdapat puting susu yang datar atau terbenam.[10]

Cara yang dapat dilakukan untuk mengatasi adalah dengan mengeluarkan ASI dengan menyusukannya, sebelum disusukan payudara harus dimasase terlebih dahulu dan ASI diperas lembut dengan tangan. Dan payudara dapat dikompres dengan menggunakan air hangat agar kekejangan pembuluh darah vena berkurang untuk mengurangi rasa nyeri, sebaliknya dapat dikompres bergantian dengan air hangat agar aliran darah payudaralancar.[10] Pembengkan payudara merupakan suatu alasan ibu untuk menghentikan pemberian ASI atau alasan untuk memulai memberikan tambahan minuman atau makanan lain selain ASI, sehingga kebanyakan ibu tidak memberikan ASI secara eksklusif kepada bayinya.

\section{2) Hubungan Antara Pelaksanaan IMD Dengan Pemberian ASI eksklusif}

Berdasarkan hasil penelitian yang dilakukan jumlah responden yang tidak memberikan ASI ekslusif dan tidak melakukan inisiasi menyusu dini (69,2\%) lebih besar dibandingkan dengan jumlah responden yang memberikan ASI eksklusif dan melakukan inisiasi menyusu dini yaitu 53,1\%. .Dari hasil analisis statistik yang dilakukan diperoleh nilai $\mathrm{p}$ value $=0,047$ lebih kecil dari $\alpha=0,05$, jadi dapat disimpulkan bahwa ada hubungan yang signifikan antara pelaksanaan inisiasi menyusu dini dengan pemberian ASI eksklusif pada ibu yang memiliki bayi usia 0-6 bulan di Kecamatan Tangaran Kabupaten Sambas.

Hasil penelitian ini sejalan dengan penelitian yang dilakukan oleh Rengginasarimenunjukkan bahwa terdapat hubungan antara pelaksanaan inisiasi menyusu dini dengan pemberian ASI eksklusif ( $p$ value $=0,012)$. [10]

Keberhasilan atau kegagalan memberikan ASI secara eksklusif dapat diawali dengan keberhasilan atau kegagalan dalam memberikan 
kesempatan menyusu satu jam pertama setelah kelahiran.[11] Ibu yang melakukan IMD merasa semakin percaya diri untuk menyusui bayinya sehingga merasa tidak perlu memberikan makanan/minuman apapun kepada bayinya.[12]

Kegagalan dalam melakukan IMD dalam penelitian ini dikarenakan oleh ibu yang tidak sabar untuk memeberikan ASI kepada bayinya setelah lahir dan ibu merasa bosan jika bayi diletakkan diatas dadanya terlalu lama (< dari 1 jam), serta disebabkan karena petugas kesehatan khususnya bidan yang membantu persalinan tidak melakukan IMD kepada ibu yang bersalin. Sehingga banyak ibu yang tidak melakukan IMD atau tidak berhasil melakukan IMD setelah persalinan.

\section{3) Hubungan Antara Paparan Iklan Susu Formula Dengan Pemberian ASI Eksklusif}

Berdasarkan hasil penelitian yang dilakukan bahwa jumlah responden yang tidak memberikan Asi ekslusif dan yang terpapar iklan susu formula (64,9\%) lebih besar dibandingkan dengan jumlah responden yang memberikan ASI eksklusif dan tidak terpapar iklan susu formula yaitu42,4\%. Dari hasil analisis statistik yang dilakukan diperoleh nilai $\mathrm{p}$ value $=0,606$ lebih besar dari $\alpha=0,05$, jadi dapat disimpulkan bahwa tidak ada hubungan yang signifikan antara iklan susu formula dengan pemberian ASI eksklusif pada ibu yang memiliki bayi usia 0-6 bulan di Kecamatan Tangaran Kabupaten Sambas. Meskipun variabel ini tidak memiliki hubungan yang signifikan dengan pemberian ASI eksklusif, tetapi variabel ini ada risiko untuk tidak memberiankan ASI ekslusif karena nilai $P R=1,128$.

Iklan susu formula banyak mempengaruhi para ibu untuk mencoba atau terus memberikan susu formula ke anaknya. Produk susu formula yang diperkenalkan kepada ibu-ibu rumah tangga disajikan dalam bentuk dan kemasan yang menarikyang ditawarkan dalam berbagai cara, salah satunya melalui iklan di televisi.[13]

Iklan tersebut menghadirkan seorang ahli kesehatan anak dan anakanak yang dihadarikan dalam iklan tersebut kelihatan sehat, cerdas, dan pemberani setelah diberikan susu formula yang diiklankan.Gencarnya iklan susu formula tersebut menyebabkan ibu beranggapan bahwa susu formula sama baiknya atau bahkan lebih baik daripada ASI, sehingga ibu lebih memilih untuk memberikan susu formula kepada bayinya.

\section{SIMPULAN DAN SARAN Simpulan}

1. Tidak terdapat hubungan yang signifikan antara kondisi kesehatan ibu dengan pemberian ASI ekslusif di Kecamatan Tangaran ( $p$ value $=0,071$ dan PR CI $95 \%=1,371 \quad(0,985$ 1,909)).

2. Terdapat hubungan yang signifikan antara pelaksanaan inisiasi menyusu dini dengan pemberian ASI ekslusifdi Kecamatan Tangaran ( $p$ value $=0,047$ dan PR CI $95 \%=1,477 \quad(0,993-$ 2,198)).

3. Tidak terdapat hubungan yang signifikan antara ketepaparan iklan susu formula dengan pemberian ASI ekslusif di Kecamatan Tangaran (pvalue $=0,606$ dan PR CI 95\% = $1,128(0,806-1,578))$.

\section{Saran}

Diharapkan Saran bagi tenaga kesehatan dan dinas kesehatan untuk 
memberikan penjelasan mengenai pemberian ASI eksklusif, menyediakan klinik laktasi, persalinanditolong oleh bidan (tenaga kesehatan).

\section{DAFTAR RUJUKAN}

[1] Kemenkes RI. 2013.Riset Kesehatan Dasar, Badan Penelitian dan Pengembangan Kesehatan. Jakarta.

[2] Notoatmodjo, Soekidjo. 2007. Kesehatan Masyarakat Ilmu dan Seni.Jakarta : Rineka Cipta.

[3] Suradi, Rulina., et al, 2010. Indonesia Menyusui.Jakarta : IDAI.

[4] Hidayat, M.S.M. 2013. Faktor-faktor yang berhubungan dengan pemberian ASI eksklusif pada ibu yang melahirkan di luar rumah bersalin Puskesmas kecamatan Pesanggrahan Jakarta Selatan tahun 2013. Skripsi. Prodi Kesehatan Masyarakat-Universitas Islam Negeri Syarif Hidayatullah Jakarta (dipublikasikan).

[5]

UNICEF,2011.Breastfeeding.http: //www.unicef.org/nutrition/index 24824. html. [diakses06 Oktober 2015].

[6] Kemenkes RI. 2012. Kinerja Kegiatan Pembinaan Gizi Tahun 2011 Menuju Perbaikan Gizi Perseorangan Dan Masyarakat Yang Bermutu.Jakarta :Kementerian Kesehatan RI.
[7] Dinkes Propinsi Kalbar, 2012. Profil Kesehatan Propinsi Kalimantan Barat. Pontianak.

[8] Dinkes Kab Sambas. 2014. Profil Kesehatan Kabupaten Sambas. Sambas.

[9] Atabik, Ahmad. 2012. Faktor Ibu Yang Berhubungan Dengan Praktik Pemberian ASI Eksklusif Di Wilayah Kerja Puskesemas Pamotan.Jurnal Kesehatan Masyarakat, Vol 3 No 1.p1

[10] Nugroho, Taufan. 2011. ASI dan Tumor Payudara. Yogyakarta : Nuha Medika.

[11] Priscilla, Vetty and Elmatris. 2010.Hubungan Pelaksanaan Menyusui Dini Dengan Pemberian ASI Eksklusif Di Wilayah Kerja Puskesmas Tanah Garam Kota Solok. Jurnal Kesehatan Masyarakat. Vol 6 No 1.p 19.

[12] Rengginasari, E., Kapantow, N.H., and Rombot, D.V.2014.Hubungan Antara Pekerjaan Ibu, Dukungan Suami Dan Inisiasi Menyusui Dini Dengan Pemberian ASI Eksklusif Di Puskesmas Tuminting Kota Manado. Manado. Jurnal Kesehatan Masyarakat. Vol 2 No 1.p3-7.

[13] Dartianingrum, P.A. 2014. Pengaruh Tayangan Iklan Televisi Susu Sgm Terhadap Perilaku Ibu Rumah Tangga Dalam Pemberian Susu Formula Pada Anak Batita Di Posyandu Perdana Empat Lima Kelurahan Gunung Kelua Samarinda. Jurnal Ilmu Komunikasi, Vol 2 No 4.p1-8. 